\title{
Orbital abscess caused by Exophiala dermatitidis following posterior subtenon injection of triamcinolone acetonide: a case report and a review of literature related to Exophiala eye infections
}

Chiharu Iwahashi ${ }^{1 \dagger}$, Hiroshi Eguchi ${ }^{1 *}$ (D), Fumika Hotta ${ }^{1 \dagger}$, Mayu Uezumi ${ }^{2 \dagger}$, Miki Sawa $^{2 \dagger}$, Masatomo Kimura ${ }^{3 \dagger}$, Takashi Yaguchi $^{4+}$ and Shunji Kusaka ${ }^{1+}$

\begin{abstract}
Background: Subtenon injection of triamcinolone acetonide (STTA) has been widely adopted in the clinical setting of ophthalmology and its infectious complications are rare. However, orbital abscess following STTA has been reported in seven cases. Furthermore, although eye infections due to Exophiala species are uncommon, there have been 19 cases to date. E. jeanselmei, E. phaeomuriformis, E. werneckii, and E. dermatitidis have been reported to cause human eye infections; however, to the best of our knowledge, orbital abscess caused by $E$. dermatitidis has not yet been reported. We describe the first documented case of fungal orbital abscess caused by E. dermatitidis following STTA. We also review the related literature of orbital abscess following STTA, as well as eye infections caused by the four Exophiala species.
\end{abstract}

Case presentation: The patient was a 69-year-old Japanese woman with diabetic mellitus. She had a macular oedema in her right eye, which occurred secondary to branch retinal vein occlusion. An orbital abscess caused by E. dermatitidis occurred 4 months after the second STTA for the macular oedema, which was successfully treated by a surgical debridement and systemic administration of voriconazole.

Conclusions: Our findings in the patient and from our literature survey caution ophthalmologists to the fact that STTA can cause fungal orbital infections, especially in diabetic patients. Furthermore, surgical treatment is one of the most important risk factors.

Keywords: Orbital abscess, Exophiala dermatitidis, Subtenon injection, Voriconazole, Pseudallescheria boydii/ Scedosporium apiospermum complex

\footnotetext{
* Correspondence: hiroegu0113@gmail.com

${ }^{\dagger}$ Chiharu Iwahashi, Fumika Hotta, Mayu Uezumi, Miki Sawa, Masatomo

Kimura, Takashi Yaguchi and Shunji Kusaka contributed equally to this work.

'Department of Ophthalmology, Faculty of Medicine, Kindai University, 377-2,

Ohonohigashi, Osakasayama-shi, Osaka 589-8511, Japan

Full list of author information is available at the end of the article
}

(c) The Author(s). 2020 Open Access This article is licensed under a Creative Commons Attribution 4.0 International License, which permits use, sharing, adaptation, distribution and reproduction in any medium or format, as long as you give appropriate credit to the original author(s) and the source, provide a link to the Creative Commons licence, and indicate if changes were made. The images or other third party material in this article are included in the article's Creative Commons licence, unless indicated otherwise in a credit line to the material. If material is not included in the article's Creative Commons licence and your intended use is not permitted by statutory regulation or exceeds the permitted use, you will need to obtain permission directly from the copyright holder. To view a copy of this licence, visit http://creativecommons.org/licenses/by/4.0/. The Creative Commons Public Domain Dedication waiver (http://creativecommons.org/publicdomain/zero/1.0/) applies to the data made available in this article, unless otherwise stated in a credit line to the data. 


\section{Background}

Exophiala dermatitidis, formerly known as Wangiella dermatitidis, is a saprophytic black yeast-like fungus. It is widely distributed in the natural environment, such as soil and dead trees, and it has been isolated from humid indoor habitats such as bathtub water, dishwashers, and humidifiers [1,2]. Although human infections caused by E. dermatitidis are rare, this fungus can occasionally cause subcutaneous and systemic infections. Of the eye infections caused by the Exophiala species, we found 19 case reports in the English literature, which identified the species of the causative strains. At present, four species, namely E. dermatitidis, E. jeanselmei, E. phaeomuriformis, and E. werneckii, have been reported to be the causative species of eye infections [3-20].

Subtenon injection of triamcinolone acetonide (STTA) has been widely adopted to treat macular oedema secondary to diabetic retinopathy, branch retinal vein occlusion (BRVO), and uveitis. Although infectious complications following STTA are uncommon, endophthalmitis [21], scleritis [22, 23], and orbital abscess [21, 24-28] have been reported. Furthermore, only two cases of fungal orbital abscess following STTA were found to have been reported so far [21-25]. To the best of our knowledge, orbital abscess following STTA caused by E. dermatitidis has not been documented.

Herein, we describe the first documented case of orbital abscess caused by E. dermatitidis following STTA, which was successfully treated by surgical debridement and systemic voriconazole administration. We have also reviewed related literatures on infectious orbital abscess following STTA, including fungal infections, and of eye infections caused by four Exophiala species. A literature search in PubMed was undertaken in March 2020 using the following terms: Exophiala, eye infections, keratitis, endophthalmitis, mycetoma, and orbital abscess, and various combinations of these terms.

This study will contribute to alert ophthalmologists to the possibility of fungal infection following STTA and to spread knowledge about eye infections caused by Exophiala species.

\section{Case presentation}

A 69-year-old Japanese woman had a macular oedema in her right eye, which occurred secondary to BRVO and was unresponsive to intravitreal injection of antivascular endothelial growth factor aflibercept. She was subsequently treated by STTA injection at the referral hospital twice. During the treatments, her eye was anaesthetized with $4 \%$ topical lidocaine. A sterilized eyelid speculum was used, and the superior-temporal conjunctiva was incised using sterilized scissors to inject $20 \mathrm{mg}$ of triamcinolone acetonide into the posterior subtenon space. After the injection, the conjunctiva was not sutured because this step is usually unnecessary. These procedures were performed in an outpatient treatment room with wearing sterilized gloves. A $1.5 \%$ topical levofloxacin ophthalmic solution was administered four times daily for 3 days post-injection. Four months after the second injection, the patient noted a conjunctival mass that became progressively larger with a little pain and redness. She was then referred to Kindai University with a clinical diagnosis of orbital fat herniation.

During her first visit, best-corrected visual acuity (BCVA) was 6/30 in the right eye and 6/6 in the left eye. Intraocular pressure was normal in both eyes. Slit-lamp microscopic examination revealed no inflammation in both the anterior chamber and vitreous. A soft, welldemarcated mass mimicking herniated orbital fat was observed in the super-temporal quadrant, which corresponded to the posterior STTA site (Fig. 1a). Magnetic resonance imaging (MRI) of the orbits revealed a hypointensity lesion on T2-weighted imaging at the supertemporal peribulbar area (Fig. 1b). Her white cell count and $C$ reactive protein levels were normal.

To excise the conjunctival mass, first, we made an incision in the conjunctiva, and found that yellowish pus was discharged. The local administration of antibiotics was performed empirically based on the presumed diagnosis of bacterial infection. Although a strain of dematiaceous fungi was isolated from the pus 1 month later, the antifungal drug susceptibility of the strain was not determined at that time. We did not immediately administer antifungal drugs because there were no significant changes in clinical findings initially. The abscess was debrided again 2 months after the surgery through a superior forniceal incision because the orbital abscess at the same lesion had developed gradually. During the second surgery, the wound was irrigated with $0.1 \%$ amphotericin B after three large abscesses were removed. Postoperatively, she was treated with $400 \mathrm{mg} /$ day of oral voriconazole because of Fungiflora $\mathrm{Y}$ staining of the pus (Fig. 2a) and the presence of a large amount of fungi by pathological examination of the abscess by Grocott's staining (Fig. 2b).

We obtained the pathogenic strain from the abscess during the second surgery and observed it macroscopically and microscopically. The colony on potato dextrose agar medium (PDA; Difco, Becton, Dickinson and Company, Sparks, USA) had a diameter of $10 \mathrm{~mm} 14$ days after inoculation and with incubation at $25^{\circ} \mathrm{C}$. The colony appeared as a moist-form pigmented yeast-like colony (Fig. 3a). The slide culture using lactophenol cotton blue staining revealed cylindrical conidogenous cells producing ellipsoidal conidia (Fig. 3b). From the Basic Local Alignment Search Tool search using the sequence of the ribosomal RNA gene internal transcribed spacer domain base, the sequence (the accession number 

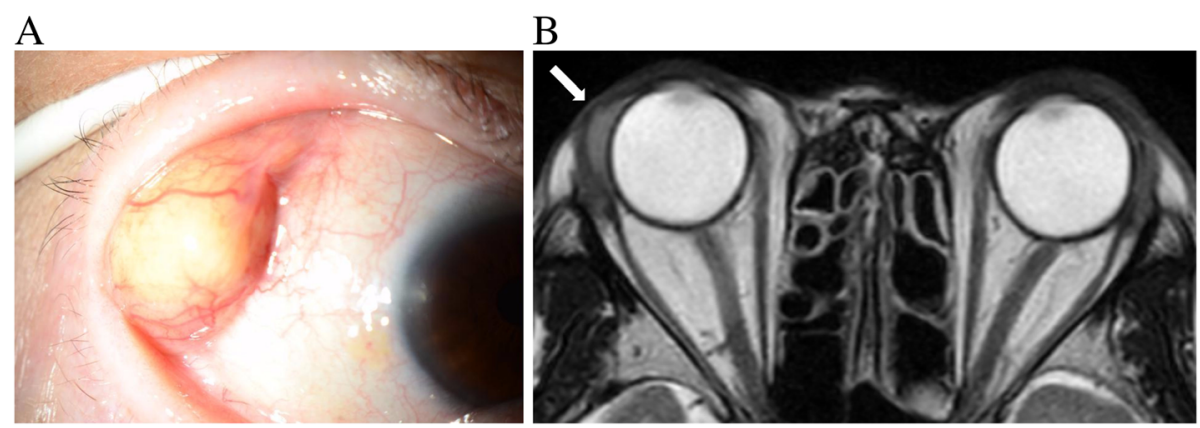

Fig. 1 a. An image of anterior segments. Well-demarcated mass mimicking herniated orbital fat was observed in the superior-temporal quadrant. b. Magnetic resonance imaging of the orbit. A hypo-intense lesion on T2-weighted images at the temporal peribulbar area was found

LC566592 in the DDBJ) of this strain showed 100\% similarity to those of some strains of $E$. dermatitidis. The isolate was thus identified as $E$. dermatitidis on the basis of morphology and phylogeny. The pathogenic strain in the current case was deposited at the Medical Mycology Center, Chiba University in Japan, as IFM 65961.

Minimum inhibitory concentrations (MICs) of several antifungal drugs and the minimal effective concentration of micafungin against the strain were determined using of the broth dilution method according to M38-A2 of the Clinical and Laboratory Standard Institute (Table 1). The inhibitory concentrations of amphotericin B, itraconazole, voriconazole, and miconazole against the pathogenic strain were found to be low. Based on these results, topical and systemic voriconazole were administered for 3 months. The patient's serum beta-D-glucan levels were normal during the follow-up periods since the first surgery, and no recurrence was observed after the second drainage.

\section{Discussion and conclusion}

Periocular infection is a rare complication following STTA with a reported incidence of $0.04 \%$ in the Japanese population [29]. As listed in Table 2, two of the six reported infectious orbital abscesses following STTA were caused by fungi, whereas the rest were caused by bacteria. The causative fungi have been identified as the Pseudallescheria boydii/Scedosporium apiospermum complex. At present, the reason why only Scedosporium species have been reported as the causative fungi of orbital abscesses following STTA is uncertain. However, $S$. apiospermum is classically known to cause traumaassociated infections in healthy individuals, and it certainly can cause infections in immunocompromised hosts [30]. Its abundance has also been correlated with human impact on environments [31], particularly with increasing level of diesel fuels and elevated temperatures [32]. Given that urban soils can reach high temperatures even in countries with temperate climates [32], the ocular surface of individuals living in urban areas with temperate climates is expected to be more exposed to $S$. apiospermum.

Interestingly, as listed in Table 3, most of the reported cases of eye infection caused by Exophiala had a history of certain surgical interventions [3, 4, 6-8], which may have caused trauma to human tissues. E. dermatitidis can be isolated from environments where human impact is present, similarly to $S$. apiospermum [33]. Both reported patients with fungal abscess following STTA, along with the present study subject, had diabetes
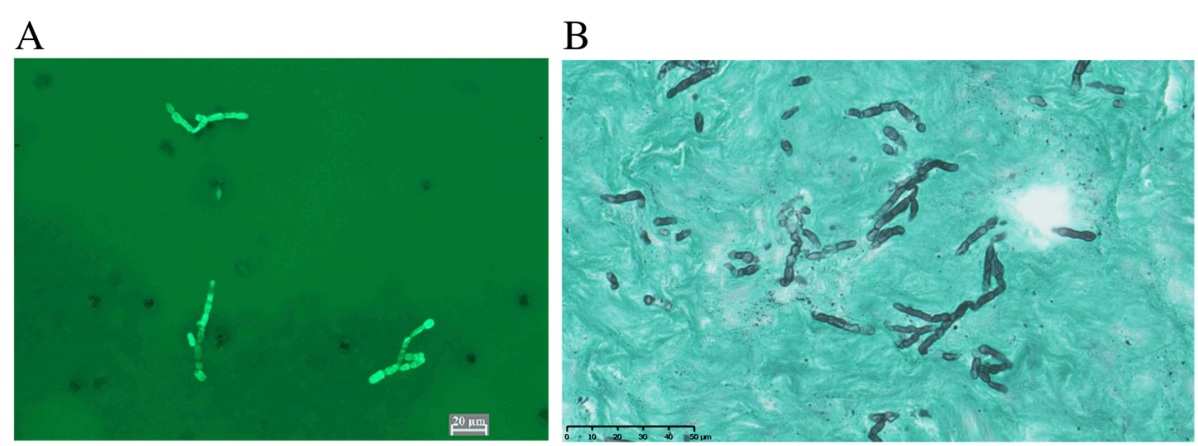

Fig. 2 a. Fungiflora $Y$ staining of the pus. Fungi were found. b. Pathological examination of the abscess by Grocott's staining. Fungi were still found in the excised abscess 

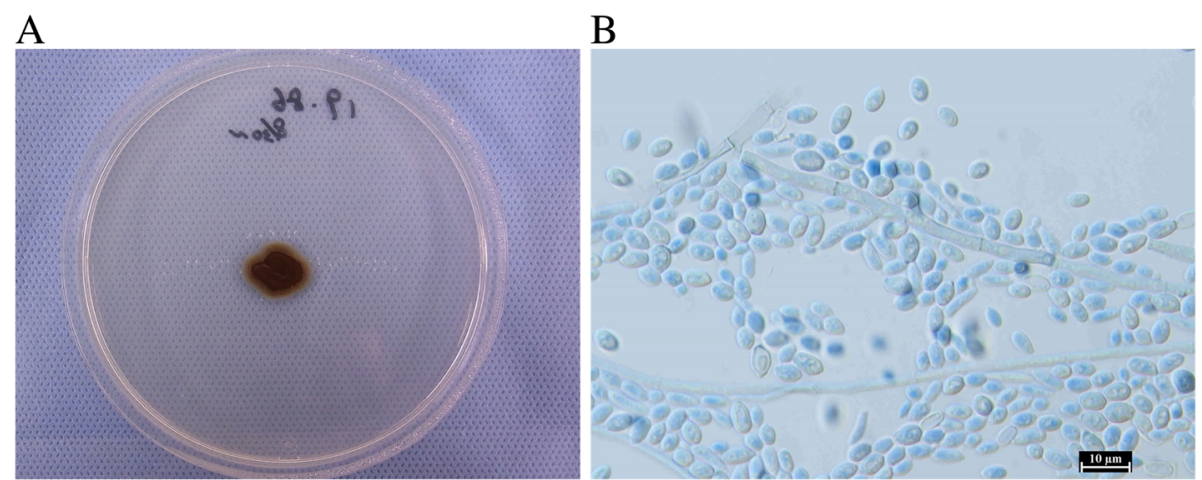

Fig. 3 a. An image of a large colony on potato dextrose agar medium. The pigmented, moist form of a yeast-like colony 14 days after inoculation is shown

mellitus, which might have made them susceptible to fungal eye infection because of local immunosuppressive conditions. Therefore, diabetes mellitus should be considered as the highest risk factor of fungal orbital infection following STTA, and E. dermatitidis and $S$. apiospermum should be considered as the causative pathogens.

The possibility of serum fungal infection in the present case was very low because her serum beta-D-glucan level was within the normal range throughout the follow-up periods since the first surgery. We speculate that the cause of exogenous origin was direct contact with polluted soil or rubbing the eyes with contaminated fingers after handling polluted indoor habitats, thereby allowing the pathogenic strain to access the subtenon space via conjunctival incision early after the STTA procedure. Given the extremely low frequency of infectious complications following STTA performed in the referral hospital and with the study being the only case out of more than 2000 STTA cases similarly conducted for more than 20 years, we speculate the iatrogenic transmission route to be very unlikely. We presume that this patient had a certain affinity to $E$. dermatitidis, probably from

Table 1 Susceptibility of antifungal agents for Exophiala dermatitidis

\begin{tabular}{ll}
\hline Antifungal agents & MIC/MEC $(\mu \mathrm{g} / \mathrm{mL})$ \\
\hline Micafungin & 4 \\
Caspofungin & 16 \\
Amphotericin B & 1 \\
Flucytosine & 4 \\
Fluconazole & 16 \\
Itraconazole & 1 \\
Voriconazole & 0.5 \\
Miconazole & 1 \\
\hline
\end{tabular}

MEC minimum effective concentration, MIC minimum inhibitory concentration the polluted humid indoor environments in her house; however, no interview about her living environment was done. Alternatively, a strain of E. dermatitidis could have colonized on her ocular surface, given the fact that yeasts, including $E$. dermatitidis, have been cultured from the corneas of healthy cadavers, but more yeasts were isolated from the corneas of diabetic cadaver [34]. It should be noted that STTA, through small conjunctival incisions, possibly causes fungal orbital infection, even if sterilized instruments were used following ocular surface disinfection.

To date, four Exophiala species, namely E. jeanselmei, E. phaeomuriformis, E. werneckii, and E. dermatitidis have been isolated from human eye infections. We have listed all the studies published in English that performed specieslevel identification of the causative strain (Table 3). There is no tendency for certain species of Exophiala to have a higher affinity towards certain parts of the eye. However, $E$. jeanselmei and $E$. dermatitidis have higher affinities to the human eye than the other species do [3-16]. Interestingly, in the past 5 years, E. phaeomuriformis has been reported as a causative strain of eye infections. In 2018, the first case of $E$. phaeomuriformis keratitis was reported from subarctic region [18]. The emergence of Exophiala spp., which are pathogenic to the human eye, suggests that the increase in Exophiala eye infections might be related to global warming given that $E$. phaeomuriformis and E. dermatitidis grow at $45-47^{\circ} \mathrm{C}$ [35]. To determine whether this trend would continue, case accumulation is required. Regarding the ocular involvement of $E$. dermatitidis, keratitis, subconjunctuval mycetoma, and endophthalmitis have been reported. Four of six Exophiala endophthalmitis cases did not heal, which led to poor visual outcome. If not treated properly, endophthalmitis may occur secondary to orbital abscess; therefore, the surgical debridement of a fungal abscess and appropriate administrations of antifungal agents were effective in the current case. As shown in Table 2, bacterial orbital abscess develops within 4-6 weeks, whereas fungal 
Table 2 Reported cases of orbital abscess after posterior subtenon injection of triamcinolone acetonide (STTA)

\begin{tabular}{|c|c|c|c|c|c|c|}
\hline \multirow{2}{*}{$\begin{array}{l}\text { Age/ } \\
\text { Sex }\end{array}$} & \multirow{2}{*}{$\begin{array}{l}\text { Year } \\
\text { reported }\end{array}$} & \multicolumn{2}{|l|}{ Comorbidities } & \multirow[t]{2}{*}{ Duration $^{a}$} & \multirow[t]{2}{*}{ Causative pathogen } & \multirow[t]{2}{*}{ Reference } \\
\hline & & Focal & Systemic & & & \\
\hline $90 / F$ & 2004 & BRVO, ME & None & 3 weeks & Staphylococcus aureus & {$[24]$} \\
\hline $62 / F$ & 2007 & DME & DM & 2 months & Pseudallescheria boydii & {$[25]$} \\
\hline $50 / \mathrm{M}$ & 2007 & Uveoscleritis & Behçet disease, DM & 2 weeks & Nocardia species & {$[26]$} \\
\hline $54 / F$ & 2008 & DME & DM, HT & 3 days & Gram-positive cocci & {$[27]$} \\
\hline $58 / \mathrm{M}$ & 2009 & DME & $\mathrm{DM}$ & 3 months & Scedosporium apiospermum & {$[21]$} \\
\hline $57 / \mathrm{M}$ & 2017 & CME & Atopic dermatitis & 6 weeks & Staphylococcus aureus & {$[28]$} \\
\hline $69 / F$ & 2020 & BRVO, ME & $\mathrm{DM}$ & 4 months & Exophiala dermartitidis & The current case \\
\hline
\end{tabular}

$F$ female, $M$ male, BRVO branch retinal vein occlusion, DME diabetic macular oedema, CME cystoid macular oedema, DM diabetes mellitus, $H T$ hypertension ${ }^{a}$ Duration denotes periods from the last STTA

orbital abscess develops after 2-3 months. In the present case, orbital abscess occurred 3 months after the second STTA and recurred 2 months after the first surgery. Hence, careful monthly monitoring is required after STTA. Diagnostic imaging using MRI should be performed if orbital abscess is suspected. If necessary, a prompt surgical approach should be considered because $E$. dermatitidis can cause infection in the central nervous system, leading to fatal consequences [36, 37].

The study of in vitro antifungal susceptibilities of environmental Exophiala isolates has shown that the most active antifungal agents are voriconazole and terbinafine, followed by posaconazole, itraconazole and amphotericin B, and that fluconazole has no meaningful antifungal activity against Exophiala [38]. In the current case, the recurrence of orbital abscess was observed without antifungal systemic treatment in the postoperative period of the first surgery. Therefore, after the second surgical debridement, we had administered systemic voriconazole for 3 months based on the susceptibility of antifungal drugs and no recurrence was observed. Prolonged systemic antifungal administration is required for the treatment of fungal orbital infection.

Table 3 Reported cases of eye infection caused by Exophiala as classified by species

\begin{tabular}{|c|c|c|c|c|c|c|c|}
\hline Species & Diseases & Age/Sex & Outcome & Possible etiologies & Year & Country & Reference \\
\hline \multirow[t]{8}{*}{ E. dermatitidis } & Orbital abscess & $69 / F$ & Healed & STTA, DM & 2020 & Japan & The current case \\
\hline & Endophthalmitis & $59 / \mathrm{M}$ & Healed & Cataract surgery & 2018 & India & {$[3]$} \\
\hline & Endophthalmitis & $60 / M$ & Not healed & PK & 2014 & USA & {$[4]$} \\
\hline & Subconjunctival mycetoma & $44 / F$ & Healed & unknown & 2010 & Hong Kong & {$[5]$} \\
\hline & Keratitis & $52 / F$ & Healed & LASIK & 2006 & USA & {$[6]$} \\
\hline & Keratitis & $75 / \mathrm{M}$ & Not healed & PK, steroid & 2006 & Taiwan & {$[7]$} \\
\hline & Keratitis & $31 / \mathrm{M}$ & Not healed & PK & 1999 & France & {$[8]$} \\
\hline & Keratitis (corneal abscess) & $35 / \mathrm{M}$ & Healed & Recklinghausen's disease & 1990 & Czechoslovakia & {$[9]$} \\
\hline \multirow[t]{8}{*}{ E. jeanselmei } & Keratitis & $41 / \mathrm{M}$ & Healed & Plant injury & 2013 & USA & [10] \\
\hline & Subconjunctival mycetoma & $76 / \mathrm{M}$ & Not healed & STTA & 2009 & USA & [11] \\
\hline & Keratitis & $39 / F$ & Healed & LASIK, rock-climbing & 2008 & USA & [12] \\
\hline & Keratitis & $58 / F$ & Healed & Trauma & 2002 & Israel & [13] \\
\hline & Endophthalmitis & $67 / \mathrm{M}$ & Not healed & Cataract surgery, steroid & 1999 & Brazil & {$[14]$} \\
\hline & Endophthalmitis & $52 / F$ & Not healed & Cataract surgery, DM & 1999 & Brazil & [14] \\
\hline & Keratitis & $42 / \mathrm{M}$ & Not healed & - & 1993 & Saudi Arabia & {$[15]$} \\
\hline & Endophthalmitis & - & Not healed & Trauma & 1983 & - & [16] \\
\hline \multirow[t]{3}{*}{ E. phaeomuriformis } & Keratitis & $67 / M$ & Healed & $\mathrm{KPrO}, \mathrm{CL}$ & 2018 & USA & {$[17]$} \\
\hline & Keratitis & $81 / F$ & Healed & Laser treatment, $\mathrm{CL}$ & 2018 & Sweden & [18] \\
\hline & Keratitis & $84 / F$ & Healed & PK & 2017 & USA & [19] \\
\hline E. werneckii & Endophthalmitis & $83 / F$ & Healed & Not determined & 2000 & USA & {$[20]$} \\
\hline
\end{tabular}

$F$ female, $M$ male, STTA subtenon injection of triamcinolone acetonide, PK penetrating keratoplasty, LASIK laser in situ keratomleusis, DM diabetes mellitus, KPro keraoprosthesis, $C L$ contact 
In conclusion, ophthalmologists should be aware that STTA can cause fungal orbital infections, especially in diabetic patients. Surgical treatment is one of the highest risk factors. E. dermatitidis, along with the Pseudallescheria boydii/Scedosporium.

apiospermum complex, should be considered as a causative pathogen. The monthly monitoring of clinical findings obtained using diagnostic imaging and a surgical debridement in an optimal period is crucial. Systemic administration of voriconazole after the surgery is also recommended.

\section{Abbreviations}

STTA: Subtenon injection of triamcinolone acetonide; BCVA: Best-corrected visual acuity; MRI: Magnetic resonance imaging; MIC: Minimum inhibitory concentration

\section{Acknowledgements}

Not applicable.

\section{Authors' contributions}

$\mathrm{Cl}, \mathrm{HE}, \mathrm{FH}, \mathrm{MY}$, and MS treated the patient. HE performed microscopic examination and made the final diagnosis. MK performed pathological examination. TY performed molecular examination. $\mathrm{Cl}$ and HE wrote the manuscript. MK, TY, and SK reviewed the manuscript. The author(s) read and approved the final manuscript.

\section{Funding}

This work was partly supported by the National Bio-Resource Project, Japan (http://www.nbrp.jp/).

\section{Availability of data and materials}

The datasets for the current study are available from the corresponding author on reasonable request.

\section{Ethics approval and consent to participate}

No ethical approval was required as the research in this article related to microorganisms. All authors read and approved the final manuscript.

\section{Consent for publication}

Written informed consent was obtained from the patient for publication of this case report and any accompanying images. A copy of the written consent is available for review by the Editor-in-Chief of this journal.

\section{Competing interests}

The authors declare that they have no competing interests.

\section{Author details}

'Department of Ophthalmology, Faculty of Medicine, Kindai University, 377-2, Ohonohigashi, Osakasayama-shi, Osaka 589-8511, Japan. ${ }^{2}$ Department of Ophthalmology, Sakai City Medical Center, 1-1-1, Ebaraji-cho, Nishi-ku, Sakai City, Osaka 593-08304, Japan. ${ }^{3}$ Department of Diagnostic Pathology, Kindai University Faculty of Medicine, 377-2, Ohnohigashi, Osakasayama, Osaka 589-8511, Japan. ${ }^{4}$ Medical Mycology Research Center Chiba University, 1-8-1, Inohana, Chuo-ku, Chiba-shi, Chiba 260-8673, Japan.

Received: 9 May 2020 Accepted: 26 July 2020

Published online: 03 August 2020

\section{References}

1. Matsumoto T, Matsuda T, McGinnis MR, Ajello L. Clinical and mycological spectra of Wangiella dermatitidis infections. Mycoses. 1993;36:145-55.

2. Zupančič J, Novak Babič M, Zalar P, Gunde-Cimerman N. The black yeast Exophiala dermatitidis and other selected opportunistic human fungal pathogens spread from dish- washers to kitchens. PLoS One. 2016;11(2): e0148166.

3. Homa M, Manikandan P, Saravanan V, Revathi R, Anita R, Narendran V, Panneerselvam K, Shobana CS, Aidarous MA, Galgóczy L, Vágvölgyi C, Papp
T, Kredics L. Exophiala dermatitidis endophthalmitis: case report and literature review. Mycopathologia. 2018;183:603-9.

4. Clamp MF, Jumper JM, Ku CW, McDonald HR, Johnson RN, Fu AD, Lujan BJ, Cunningham ET Jr. Chronic exogenous exophiala dermatitidis endophthalmitis. Retin Cases Brief Rep. 2014;8:265-8.

5. Li EY, Yuen HK, Lung DC. Subconjunctival mycetoma as an unusual cause of tears with black deposits. Arch Ophthalmol. 2010;128:1371-2.

6. Patel SR, Hammersmith KM, Rapuano CJ, Cohen EJ. Exophiala dermatitidis keratitis after laser in situ keratomileusis. J Cataract Refract Surg. 2006;32:681-4.

7. Tsai $\mathrm{TH}$, Chen WL, Peng Y, Wang IJ, Hu FR. Dematiaceous fungal keratitis presented as a foreign body-like isolated pigmented corneal plaque: a case report. Eye (Lond). 2006;20:740-1.

8. Benaoudia F, Assouline M, Pouliquen Y, Bouvet A, Guého E. Exophiala (Wangiella) dermatitidis keratitis after keratoplasty. Med Mycol. 1999;37:53-6.

9. Pospísil L, Skorkovská S, Moster M. Corneal phaeohyphomycosis caused by Wangiella dermatitidis. Ophthalmologica. 1990;201:128-32.

10. Saeedi OJ, Lyer SA, Mohiuddin AZ, Hogan RN. Exophiala jeanselmei keratitis: case report and review of literature. Eye Contact Lens. 2013;39:410-2.

11. Galor A, Karp CL, Forster RK, Dubovy SR, Gaunt ML, Miller D. Subconjunctival mycetoma after sub-Tenon's corticosteroid injection. Cornea. 2009;28:933-5.

12. Leung EH, Moskalewicz R, Parada JP, Kovach KJ, Bouchard C. Exophiala jeanselmei keratitis after laser in situ keratomileusis. J Cataract Refract Surg. 2008;34:1809-11.

13. Ben-Simon GJ, Barequet IS, Grinbaum A. More than tears in your eyes (Exophiala jeanselmei keratitis). Cornea. 2002;21:230-1.

14. Hofling-Lima AL, Freitas D, Fischman O, Yu CZ, Roizenblatt R, Belfort R Jr. Exophiala jeanselmei causing late endophthalmitis after cataract surgery. Am J Ophthalmol. 1999;128:512-4.

15. al-Hedaithy SS, al-Kaff AS. Exophiala jeanselmei keratitis. Mycoses. 1993;36: $97-100$

16. Hammer ME, Harding S, Wynn P. Post-traumatic fungal endophthalmitis caused by Exophiala jeanselmei. Ann Ophthalmol. 1983;15:853-5.

17. Machen L, Chau FY, de la Cruz J, Sugar J, Cortina MS. Recognition of fungal keratitis in Boston type 1 keratoprosthesis: importance of awareness and novel identification of Exophiala phaemuriformis. Cornea. 2018;37:655-7.

18. Vicente A, Pedrosa Domellöf F, Byström B. Exophiala phaeomuriformis keratitis in a subarctic climate region: a case report. Acta Ophthalmol. 2018; 96:425-8.

19. Aggarwal S, Yamaguchi T, Dana R, Hamrah P. Exophiala phaeomuriformis fungal keratitis: case report and in vivo confocal microscopy findings. Eye Contact Lens. 2017;43:e4-6.

20. Huber CE, LaBerge T, Schwiesow T, Carroll K, Bemstein PS, Mamlis N. Exophiala werneckii endophthalmitis following cataract surgery in an immunocompetent indivisual. Ophthalmic Surg Lasers. 2000;31:417-22.

21. Ikewaki J, Imaizumi M, Nakamuro T, Motomura Y, Ohkusu K, Shinoda K, Nakatsuka K. Peribulbar fungal abscesss and endophthalmitits following posterior subtenon injection of triamcinolone acetonide. Acta Ophthalmol. 2009;87:102-4.

22. Todokoro D, Hoshino J, Yo A, Makimura K, Hirato J, Akiyama H. Scedosprium apiospermum infectious scleritis following posterior subtenon triamcinolone acetonide: a case report and literature review. BMC Ophthalmol. 2018;18:40.

23. Gharaee $H$, Khalife M, Poor SS, Abrishami M. Infectious scleritis after subtenon triamcinolone acetonide injection. Ocul Immunol Inflamm. 2011; 19:284-5.

24. Engelman CJ, Palmer JD, Egbert P. Orbital abscesss following subtenon triamcinolone injection. Arch Ophthalmol. 2004;122:654-5.

25. Oh IK, Baek S, Huh K, Oh J. Periocular abscess caused by Pseudallescheria boydii after a posterior subtenon injection of triamcinolone acetonede. Graefes Arch Clin Exp Ophthalmol. 2007:245:164-6.

26. Kusaka S, Ikuno Y, Ohguro N, Hori Y, Tano Y. Orbital infection following posterior subtenon triamcinolone injection. Acta Ophthalmol Scand. 2007; 85:692-3.

27. Sukhija J, Dogra MR, Ram J, Ichhpujani P, Gupta A. Acute orbital abscess complicating deep posterior subtenon triamcinolone injection. Indian J Ophthalmol. 2008;56:246-7.

28. Rhatigan M, McAnena L, McElnea E, Connell P, Fulcher T. Orbital abscess following posterior subtenon injection of triamcinolone acetonide. Orbit. 2017:36:135-6.

29. Sakamoto T, Hida T, Tano Y, Negi A, Takeuchi S, Ishibashi T, Inoue Y, Ohguro $\mathrm{N}$, Okada AA. Survey of triamcinolone acetonide for ocular diseases in Japan. Nippon Ganka Gakkai Zasshi (Japanese). 2007;111:936-45. 
30. Cortez KJ, Roilides E, Quiroz-Telles F, Meletiadis J, Antachopoulos C, Knudsen T, et al. Infections caused by Scedosporium spp. Clin Microbiol Rev. 2008;21:157-97.

31. Kaltseis J, Rainer J, de Hoog GS. Ecology of Pseudallescheri and Scedosporium species in human-dominated and natural environments and their distribution in clinical samples. Med Mycol. 2009;47:398-405.

32. Ramirez-Garcia A, Pellon A, Rementeria A, Buldain I, Barreto-Bergter E, et al. Scedosporium and Lomentospora: an updated overview of underrated opportunists. Med Mycol. 2018;56:S102-S25.

33. Matos T, de Hoog GS, de Boer AG, de Crom I, Haase G. High prevalence of the neurotrope Exophiala dermatitidis and related oligotrophic black yeasts in sauna facilities. Mycoses. 2002;45:373-7.

34. Dixon DM, Graham CR Jr, Shaffer RM, Tarantino P. Fungal flora from diabetic and non-diabetic donor corneas. Cornea. 1984-1985;3(4):281-4.

35. Gümral R, Tümgör A, Saraçıı MA, Yıldıran STT, Ilkit M, de Hoog GS. Black yeast diversity on creosoted railway sleepers changes with ambient climatic conditions. Microb Ecol. 2014;68:699-707.

36. Klasinc R, Riesenhuber M, Bacher A, Willinger B. Invasive fungal infection caused by Exophiala dermatitidis in a patient after lung transplantation: case report and literature review. Mycopathologia. 2019;184:107-13.

37. Li DM, Li RY, de Hoog GS, Sudhadham M, Wang DL. Fatal Exophiala infections in China, with a report of seven cases. Mycoses. 2011;54:136-42.

38. Gülmez D, Doğan Ö, Boral B, Döğen A, Ilkit M, de Hoog GS, Arikan-Akdagl S. In vitro activeties of antifungal drugs against environmental Exophiala isolates and review of the literature. Mycoses. 2018;61:561-9.

\section{Publisher's Note}

Springer Nature remains neutral with regard to jurisdictional claims in published maps and institutional affiliations.

Ready to submit your research? Choose BMC and benefit from:

- fast, convenient online submission

- thorough peer review by experienced researchers in your field

- rapid publication on acceptance

- support for research data, including large and complex data types

- gold Open Access which fosters wider collaboration and increased citations

- maximum visibility for your research: over $100 \mathrm{M}$ website views per year

At BMC, research is always in progress.

Learn more biomedcentral.com/submissions 